\title{
TRAINING NEEDS IN COMMERCIAL ESTABLISHMENTS IN THE AUTOMOTIVE FIELD IN COTOPAXI PROVINCE - ECUADOR
}

\author{
Argüello Maya Édison \\ Researcher and teacher of the Universidad de las Fuerzas Armadas (ESPE) in Sangolquí, Ecuador. \\ Energy and Mechanics Department \\ Cejas Magda \\ Researcher and teacher of the Universidad de las Fuerzas Armadas (ESPE). \\ Department of Economic, Administrative and Trade Sciences

\begin{abstract}
Kleber Anibal Chiluisa
Researcher and teacher of the Universidad de las Fuerzas Armadas (ESPE) in Sangolquí, Ecuador. Energy and Mechanics Department

Zambrano León Víctor

Researcher and teacher of the Universidad de las Fuerzas Armadas (ESPE) in Sangolquí, Ecuador. Energy and Mechanics Department

\section{Marco Singaña}

Researcher and teacher of the Universidad de las Fuerzas Armadas (ESPE) in Sangolquí, Ecuador. Energy and Mechanics Department
\end{abstract}

\begin{abstract}
This research work was carried out with the purpose of analyzing the training needs of automotive professionals working in commercial establishments in the province of Cotopaxi. Historically, professional training has been the main agenda of international organizations such as [1], which emphasizes in its latest report on the future of training and / or vocational training in Latin America and the Caribbean, proposing the need to take on major challenges in education and training due to changes in the labor world. This consideration of a global nature coincides with the guidelines set out in the Organic Law of Higher Education in Ecuador, where it seeks to strengthen the educational foundations through appropriate strategies to respond to the needs of the labor market. In this way, studying the training needs required by the personnel working in the automotive sector establish the need for those courses, subjects, linking programs, as well as the technical, administrative and theoretical requirements of this field in the professional practice. The study assumed a sample of nine hundred and eighty-six (986) establishments operating in the province of Cotopaxi, which allowed to diagnose the needs of the labor market in this sector and those that satisfy the University of the Armed Forces, but also those required by the sector analyzing various factors and
\end{abstract}

components. It is concluded that the institution could meet the needs required by the automotive sector of the province because it is evident that there are specialized requirements in the area in order that the professionals who perform it add value to the productive matrix and consequently contribute to the development of the Nation's plan.

Keywords - Technology, Training Needs, Commercial Establishments, Automotive Scope

\section{INTRODUCTION}

In the field of Higher Education in Ecuador, the need to carry out studies that determine the preponderance within the framework of the efforts that determine the role of universities is increasingly evident. There are many reasons that determine this importance, including the requirements that point to the development of people, companies, universities and society based on experiences in the economic, social, technical, cultural and other fields. According to [1], these links have been qualified as part of the development of a country to generate new knowledge, so in the case of Ecuador the Organic Law of Higher Education provides the universities to "participate in the process of construction and dissemination 


\section{International Journal of Engineering Applied Sciences and Technology, 2019 Vol. 3, Issue 12, ISSN No. 2455-2143, Pages 1-6 \\ Published Online April 2019 in IJEAST (http://www.ijeast.com)}

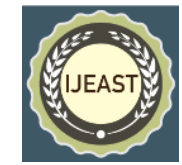

of the knowledge, contribute to local and national development in a permanent way, through community work fulfilling the principle of relevance that is that higher education responds to the expectations and needs of society, to national planning" [2]. With this background, it is worth noting that higher education institutions in Ecuador, as a rule, will articulate their teaching offer, research and activities linked to society to the academic demand and consequently to the needs of development, as well as market, occupational and demographic trends, as well as the link with the current and potential productive structure of the area of influence. Likewise, the institutions of the Higher Education System can carry out programs and courses of connection with the society guided by the academic staff and oriented to the general public. This is consistent with the current [3], which in its Objective 7 establishes the emerging need to encourage a participatory society, with a State close to the service of citizenship, in the search to develop innovative territories and creative and intelligent cities, generating networks of knowledge and linking higher education with the social and productive needs of citizens [4], which contributes to the application of this study. In this sense, the study is carried out in the interest of the Automotive Engineering Degree at the University of the Armed Forces ESPE in the city of Latacunga [4], a pioneer institution in higher education in the automotive field, as its national and international recognition identifies it as the main actor before the community related to the automotive field, and for educational services that meet the needs of professionals who are in commercial establishments that are in the automotive sector of the province of Cotopaxi.

The main objective of this study is to analyze the training needs of automotive professionals working in commercial establishments in the province of Cotopaxi, with emphasis on those subjects currently developed in the Automotive Engineering Degree at the University of the Armed Forces (ESPE). In view of the above, it is worth highlighting the methodology known as MOOC (Massive Open On-line Course) that deals with open courses on the Internet in the automotive field; identifying this methodology a variety of pedagogical practices (internet) that in one way or another contributed to the training of people in different parts of the world, positioning the best universities, such as Stanford University, Massachusetts Institute of Technology or Harvard University, and offering hundreds of free online courses; These factors, according to [5], have generated an impact on the scientific community, generating significant advances in the educational field [6].

It is possible that in Ecuador this topic of research has been little addressed, therefore, this study is developed from an exploratory, descriptive and analytical perspective in order to establish what are the training needs of the automotive professional who work in commercial establishments in the Province of Cotopaxi, Ecuador.

\section{METHOD}

\section{A. Watermark embedding algorithm -}

Science has advanced because its achievements are based on the scientific method, which in itself is a set of particular methods (modalities) that differ from each other by the type of solutions they can offer, following and respecting the procedures and techniques of each case. A method is a regular, explicit and repeatable procedure to achieve something, be it material or conceptual.

The scientific method is a model or procedure that has characterized natural science since the seventeenth century, consisting of systematic observation, measurement and experimentation, and the formulation, analysis of the object of study that has been addressed. In this way for [7] the scientific method would be the procedure by which we can achieve an objective knowledge of reality, trying to answer the questions about the order of nature. In this sense one of the aspects in the research methodology is that none of the rules expressed in advance is specific and precise enough to allow, by itself, to execute the corresponding step in the investigation. To this end, the logic of applicability of a quantitative nature in a research is based primarily on the deductive, so cut the variables to facilitate the analysis and is interested in extensive studies with representative samples in a given population, this research raises the use of the field strategy that fundamentally determines the contact with reality in a certain scenario, which takes place the production of scientific meanings in order to understand the object of study. [8,9].

Therefore, the research was of quantitative type understood as those in the magnitude of its attributes or properties can be measured in numerical terms; that is, the values that a variable acquires and can be distributed through its values along a scale.

The sample for the study was of a non-probabilistic type since the prospects were not selected at random, but the intentional choice was made of those places where there is a high concentration of workshops or establishments dedicated to the activities in question, to later proceed to the distant ones.

To determine the size of the sample, we used a publication from [10] which indicates the number of automobile establishments in the province of Cotopaxi corresponding to 986 establishments, resulting in the following formula, this value represents the population $(\mathrm{N})$ that serves to determine the sample using the corresponding statistics and sampling.

$$
n=\frac{Z^{2}(N)(p)(q)}{E^{2}(N-1)+Z^{2}(p)(q)}
$$

Among the variables for the calculation of the sample we have (p) that represents the estimated proportion of success that for this study was determined to be $50 \%$, this represents 


\section{International Journal of Engineering Applied Sciences and Technology, 2019 \\ Vol. 3, Issue 12, ISSN No. 2455-2143, Pages 1-6 \\ Published Online April 2019 in IJEAST (http://www.ijeast.com)}

the respondents who would like to receive training in the automotive field, (q) is the estimated proportion of failure in our case represents $50 \%$ that are indifferent people to receive training, these two values were considered because it is the highest value for when there is no previous study information on the subject. The variable $(\mathrm{Z})$ is the desired confidence level whose typical value is $95 \%$ but the value is placed in tables representing the area under the curve of a standard normal distribution where the value is 1.96 and $(\mathrm{E})$ which is the error of estimate and for this study it is $5 \%$ taken as a most used theoretical value; in such virtue, the value of the sample is 277, a value that determines the minimum number of surveys to be carried out (see equation 1 ).

Figure 1 reflects the information obtained from [10], the number of commercial establishments dedicated to the automotive activity in Ecuador, and Cotopaxi with a total of 986 establishments.

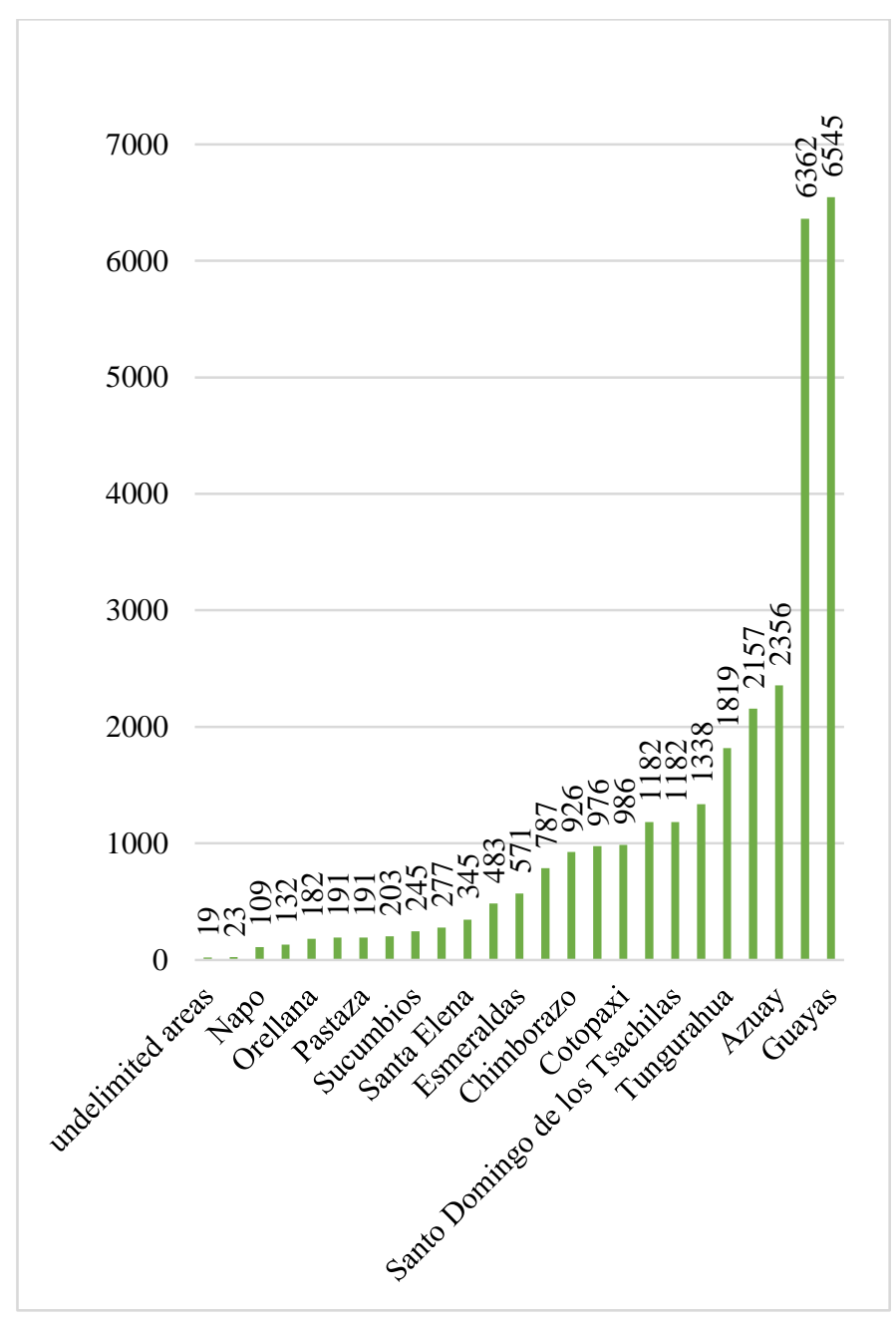

Figure 1: Number of establishments in the automotive sector by province.

To put in context, the Career of Automotive Engineering currently does not have in its planning a proposal based on the offer of courses for the public, then, [11] is used, which aims to improve the interaction with the community and the university, These normative dispositions become the most important argument to carry out corresponding surveys to the target persons to gather data about their educational needs for the good development of their work. In order to form a criterion or an idea of the profile of the personnel working in the aforementioned establishments, it is necessary to know the type of function performed by the respondent as well as their interests, for which questions were asked that were only four basic so that what was said by people be as close to reality and avoid fatigue by the length of a questionnaire divert information. It was requested to indicate the function or activity carried out in the establishment, the instruction of the prospectus to obtain the level of studies as input for future courses with the appropriate methodology, the technical and administrative areas within which the training would be desired. The questions focused on subjects taught at the university. Regardless of the position occupied in the commercial establishment, the respondent has the opportunity to indicate what kind of educational events, training or courses would be useful. In order to finalize the questionnaire, it was asked about the need for more urgent or necessary training, that is, to reaffirm the requirement or interest for some type of topic that will serve as an input for subsequent project proposals [12].

\section{RESULTS OF THE INVESTIGATION}

The study was carried out through field research in commercial establishments in the automotive area. This question sought to know the opinion of the respondents regarding a series of factors that revolve around the needs of the automotive field. One of the questions was to know what is your role or what activity you do in this establishment, which could be answered with answers as Mechanic, Administrator, Untapping, Painting, Sale of spare parts, among others [13]. Figure 2 shows the results obtained: 


\section{International Journal of Engineering Applied Sciences and Technology, 2019 Vol. 3, Issue 12, ISSN No. 2455-2143, Pages 1-6 \\ Published Online April 2019 in IJEAST (http://www.ijeast.com)}

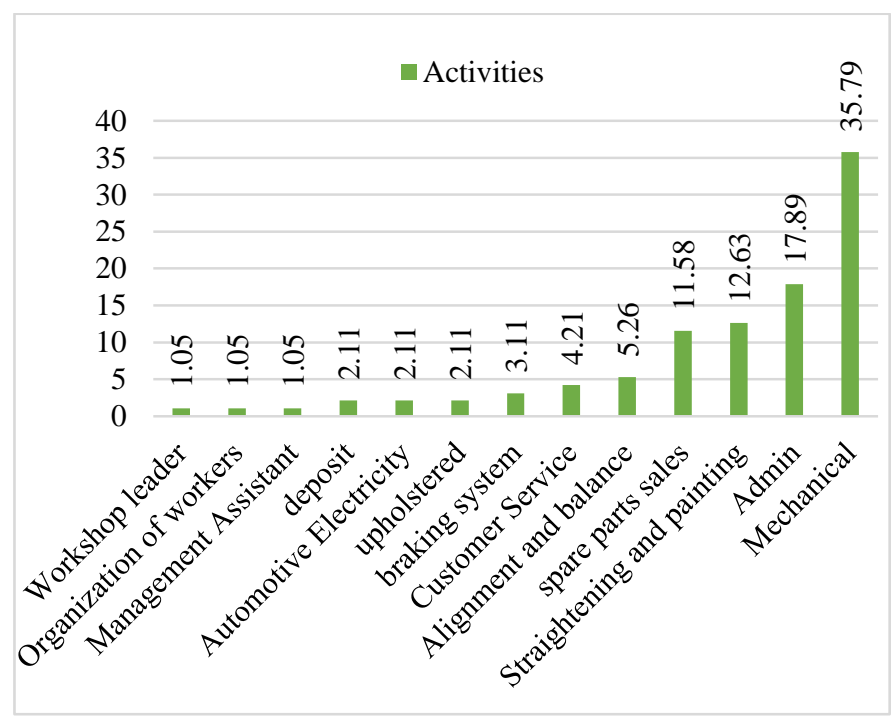

Figure 2: Activities performed by the worker and / or professional in the automotive field.

As can be seen, those consulted have considered that the most significant activity is that of mechanics, followed by being an administrator and of the straight-painting area, as well as the sale of spare parts. If we look at the previous graph, we can see the marked difference between the role of mechanic and administrator in the automotive field [14].

Next, the following question pointed to the instruction of the people who work in the establishment, for which options were offered such as: bachelor, technologist, engineering, others) obtaining the following results in figure 3 .

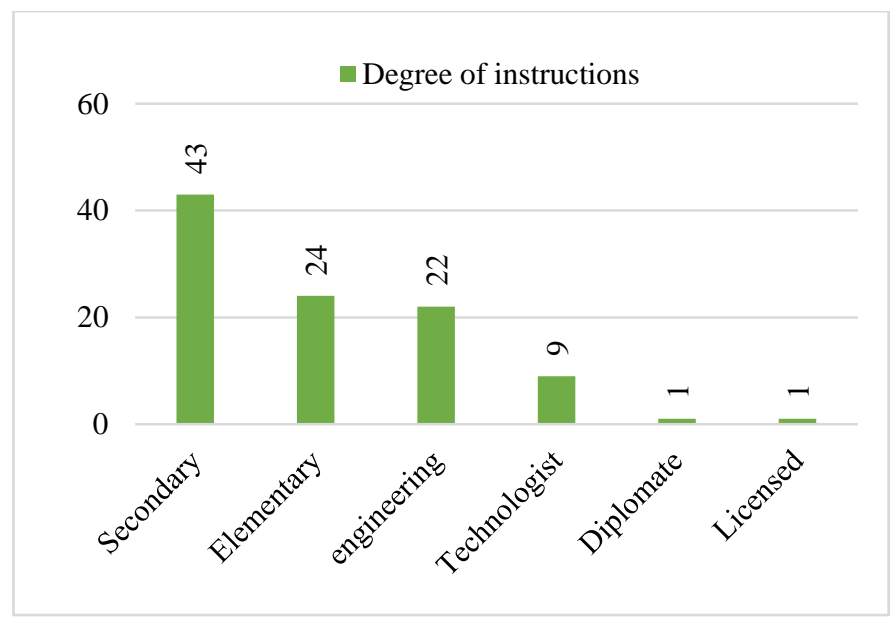

Figure 3: Degree of Instructions for personnel working in establishments in the automotive sector

The previous graph determines through the respondents that the vast majority (43\%) in the automotive field are high school graduates, followed by $24 \%$ who have barely completed primary school. It is relevant to highlight that $22 \%$ of those consulted have studied Automotive Engineering, that is, they have a specialization in the field for the performance of their activities in the establishments. With respect to $43 \%$ it is evident that a difference of almost $50 \%$ between both intervals is reflected. Then we sought to ask about the improvements of those factors inherent to the work activity, taking into account the place where he works, educational events, training and / or courses that would be useful in his professional or trade; as well as areas of the automotive sector such as: basic mechanics, automotive systems, hybrid vehicles, straightening and painting, electricity or automotive electronics, diesel engines, as well as in the administrative field, to mention a few, customer service, warehouse management or sale of spare parts [15].

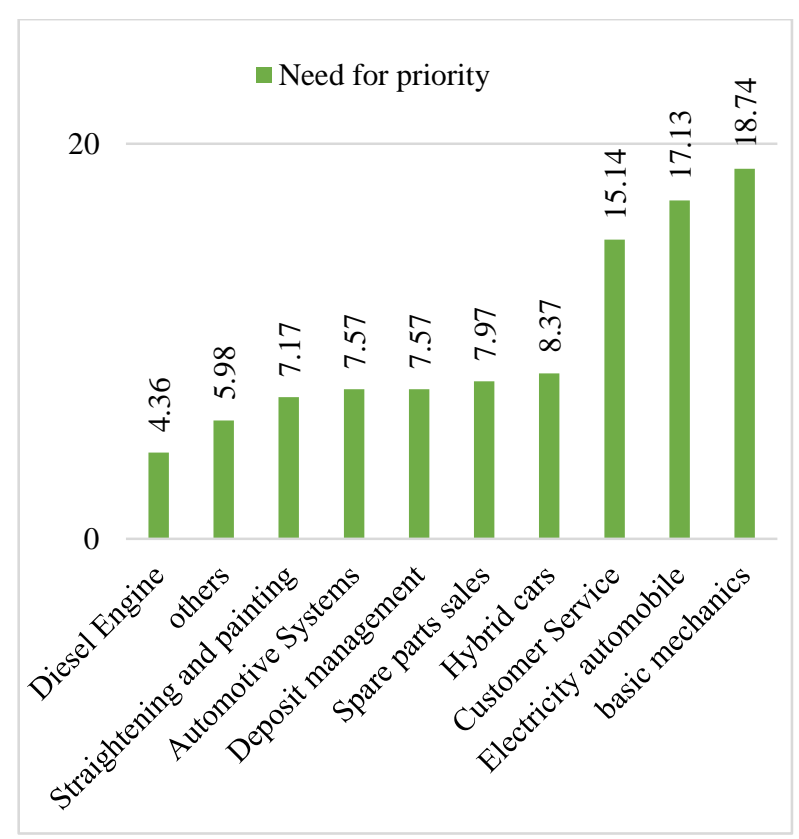

Figure 4: Need for priority training for the performance of your career and / or trade in the automotive field.

Figure 4 shows that the priority areas for which they have performed their work in the automotive field were chosen with $18.74 \%$; followed with $17.3 \%$ and $15.14 \%$ in order of priority the following: basic mechanics, electricity and automotive electronics, attention and hybrid vehicles, as shown in figure 4.

Finally, they were asked the question: What is the need for priority training for the performance of your career and / or trade in the automotive field? it reflects the results of those consulted in figure 5 below. 


\section{International Journal of Engineering Applied Sciences and Technology, 2019 \\ Vol. 3, Issue 12, ISSN No. 2455-2143, Pages 1-6 \\ Published Online April 2019 in IJEAST (http://www.ijeast.com)}

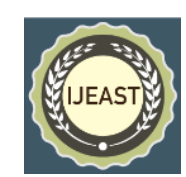

Analyzing Figure 4, it is noted that those consulted consider that training in basic mechanics has greater relevance and / or requirement for commercial establishments where the research was conducted, followed by courses related to customer service, and in a third place of needs would be electricity and automotive electronics [16].

This reflects that $61.06 \%$ of respondents work directly in contact with vehicles in activities such as: mechanics, electricity, brakes, straightening and painting. The difference made up of $38.94 \%$ would be linked to the area of administration, sale of spare parts, assistants, among others, this shows that it is a sample that reflects the reality of the different functions that exist in automotive workshops and other establishments in the sector. Even though there is a diversity of functions among the respondents, they could select according to their needs the types of educational events, trainings or courses, which according to the respondents would be more useful as it was mentioned earlier would be basic mechanics $18.74 \%$, electricity and electronics of the automobile $17,13 \%$, warehouse management $15,54 \%$ and customer service $15,14 \%$.

When confirming the interest on a subject of training with the cross-question, it is obtained that $22.11 \%$ have more urgency to train in basic mechanics, $14.74 \%$ customer service and $13.68 \%$ electricity and automobile electronics. However, another factor to take into account is that $33 \%$ of the sample has higher education. $67 \%$ have studies in elementary or high school.

\section{DISCUSSION}

The institutions of Higher Education dedicated to offer studies in the area of automotive make their students aware of the great opportunity they have to prepare in this branch of engineering. This professional line, in addition to emphasizing mechanics, combines other sciences such as mathematics, technology and materials studies. The automotive professional also develops skills, skills and knowledge that allow creating an integral component within the framework of the profession, by design processes, manufacturing and all types of automotive-mechanical system, as well as maintenance [17].

The University of the Armed Forces allows the student to have professional development both in theory and in practice, thus obtaining a comprehensive study curriculum in order to obtain a professional capable of demonstrating a competence profile according to the level of demand of the labor field . This allows managing and positioning not only the university but also the evaluation of projects with effectiveness.

In this order of ideas, according to the research proposed, in the automotive field, the University of the Armed Forces does not have an offer of courses that allow the students to continue developing their knowledge in a practical way, in addition to covering the demand of those young people who are in establishments in the performance of a trade without any basic preparation. The research also pointed out that the institutions that have links with the area are not generating the necessary supply so that the people who are in this type of establishment prepare adequately with professionals in the area and also in a technical and theoretical way, which makes more Emerging the need to cover these professional training requirements.

In the automotive field at an international level there are very fruitful experiences that have raised the quality of the institutes that prepare professionals in this area, such is the case of Massachusetts Institute of Technology, which in the area of Mechanical Engineering offers courses through the Edx portal, with orientation towards road safety in automotive engineering, engineering of automotive systems based on models, hybrid vehicles, multi-object tracking for automotive systems, among others [18]. These courses cover basic, intermediate and advanced levels according to the needs of their environment and the technological developments of the time. In addition, they have laboratories and tools related to the topics to be dealt with in the courses, facilitating and making efficient the process of technology transfer, from the university to society [12].

In such virtue the University of the Armed Forces (ESPE) has raised the baseline on the training needs of professionals in the automotive area of the province of Cotopaxi, coinciding many of the issues with those handled worldwide, by or example: basic mechanics, hybrid vehicles and customer service. Similarly, it should be noted that the results point to the area of electricity or electronics of the car as a line that is not in priority than the other areas mentioned.

\section{V.CONCLUSION}

At present it is evident the constant technological development in all aspects of the competitive world both academic and business, on the one hand it is conceived as a priority formal education to society in general and on the other hand it requires specialized professionals who are capable of generating a profile for high level competition. The relevance of this work identifies its initial purpose, which was to analyze training from the automotive field in those establishments in the province of Cotopaxi. Therefore, the sample was of 986 establishments where situations were explored regarding the object of study in this research seeking to know the needs within the framework of the training of the automotive field taking into account the characteristics of the study pensum of a recognized institution in the province whose study offer can be improved according to the real needs of the sector, both productive and technological. 


\section{International Journal of Engineering Applied Sciences and Technology, 2019 \\ Vol. 3, Issue 12, ISSN No. 2455-2143, Pages 1-6 \\ Published Online April 2019 in IJEAST (http://www.ijeast.com)}

We studied factors that determined the emerging need to train in specific areas that guarantee results and ideal performance, especially in Basic Mechanics, Electricity and basic electronics of the Automobile, Customer Service as well as the management of warehouses, in that order of priority. In the same way, the results showed the incorporation of management, administrative and / or management courses that guarantee an integral professional profile. The results presented in this research denote the preponderance of this factor (training) in favor of lines of research with systemic approaches that guarantee the generation of complementary activities to the formal one for the personnel that work in the consulted establishments. The need to create strategies linked to society is also one of the relevant results of the study, because it would generate and add value to the productive matrix of Ecuador and would comply with regulatory frameworks in education and business training in the country.

\section{REFERENCE}

[1] Chang H. G. (2010). The Model of the Triple Helix as a Medium for Linkage between the University and Business. National Journal of Administration, 1 (1), 8594. doi: http://dx.doi.org/10.22458/rna.v1i1.286

[2] National Assembly of the Republic of Ecuador (2010). Organic Law on Higher Education, Official Register No. 298, Supplement, of pp. 10-12

[3] National Secretariat of Planning and Development Senplades (2017). National Development Plan 20172021. A lifetime. Approved by Resolution. ${ }^{\circ}$ CNP-0032017 of September 22, Quito, Ecuador.

[4] University of the Armed Forces ESPE. (2018). Automotive Engineering, www.espe.edu.ec.

[5] Aguaced, I., Vázquez, E. and López, E. (2016). Bibliometric impact of the MOOC movement in the Spanish scientific community. Educación XX1, Vol. 19, $\mathrm{N}^{\mathrm{o}} \quad 2, \quad 77-104 . \quad$ Available in: http://revistas.uned.es/index.php/educacionXX1/article/do wnload/16454/18868.

[6] López, E., Vázquez, E. and Róman, P. (2015). Analysis and implications of the impact of the MOOC movement in the scientific community: JCR and Scopus (2010-13). Communicate, XXII (44), 75-77. Retrieved from: https://www.revistacomunicar.com/index.php?contenido= detalles\&numero $=44 \&$ articulo $=44-2015-08$.

[7] Mendoza, D. (2018). Estrategias de enseñanza y su efectividad en los procesos de aprendizaje en los estudiantes de turismo de la Universidad Iberoamericana de Ecuador. Espacios, 39(43). 25-39.

[8] Moreano, E., Salazar, E., Gallardo, C., Cruz, L. and Espinel, C. (2019). Application of alternative energies in The cotopaxi province, Ecuador. International Journal of
Engineering Applied Sciences and Technology, Vol. 3, Issue 11, ISSN No. 2455-2143, Pages 47-52.

[9] García, J. and Reing-Bernal A. (2013). Research Methodology. Calculation of the Sample. Direction of Investigation. General Hospital of Mexico. Mexico D.F., Mexico. Recovered: Vol. 2. Núm. 8, pp. 175-231.

[10] National Institute of Statistics and Censuses INEC. (2012). Economic establishments dedicated to automotive trade activities. $\quad$ Retrieved from http://www.ecuadorencifras.gob.ec/wpcontent/descargas/Infoconomia/info7.pdf.

[11] Waiter L. (2012). Statistics for social research. Mexico: Alfaomega.

[12] Automotive courses in EDX. Retrieved from https://www.edx.org

[13] Méndez, C. (2013). Design and implementation of massive open online courses (MOOC): expectations and practical considerations. RED. Journal of Distance Education. Number 39. December 15.

[14] Mengual, G., Vázquez, E. and López, E. (2017). Scientific productivity on MOOCs: bibliometric approach 2012-2016 through SCOPUS. RIED. Iberoamerican Journal of Distance Education. Vol 20, num 1. Retrieved on $29 . \quad$ Available in: http://revistas.uned.es/index.php/ried/article/view/16662/1 4950.

[15] Pernías, P. and Luján, S. (2014). MOOCs: origins, history and types. Obtained from Communication and Pedagogy Center: http://www.centrocp.com/los-mooc-origeneshistoria-y-tipos/.

[16] Scientific Information System Redalyc Network of Scientific Journals of Latin America and the Caribbean, Spain and Portugal. (2005). Formulas for the calculation of the sample in health research. Retrieved from http://www.redalyc.org/articulo.oa?id=48711206.

[17] Valverde, J. (2014). MOOCS: A critical vision from the education sciences. Profesorado Revista de Currículum y Formación del Profesorado, 18 (1). Retrieved from: http://digibug.ugr.es/bitstream/10481/31668/6/rev181AR T6_.pdf.

[18] Vidal, M., Listovsky, G., Zacca, G., Diaz, J., De Garcia, E. and Leon, C. (2016). Massive and open online courses (MOOCs, COMA). Retrieved from Scielo.sld.cu: http://scielo.sld.cu/scielo.php?script=sci_arttext $\&$ pid=S08 64-21412016000200021. 